\title{
DEVELOPMENT AND VALIDATION OF WEB-BASED STEAM ONLINE PLATFORM TO IMPROVE LEARNING QUALITY IN PRE-SERVICE CHEMISTRY TEACHERS
}

\author{
Elda Frediana Rety Kartika $\mathbb{D}$, Elfi Susanti VH $(\mathbb{D}$, Nurma Yunita Indriyanti $(\mathbb{D}$ \\ Universitas Sebelas Maret (Indonesia) \\ eldafrediana@gmail.com,elfisusantivh@staff.uns.ac.id,nurma.indriyanti@staff.uns.ac.id
}

Received May 2021

Accepted July 2021

\section{Abstract}

STEAM (Science, Technology, Engineering, Art, Mathematics) learning is design to promote student's interest in learning chemistry. Integration STEAM into chemistry learning is often seen as a challenge, such as not familiar and lack of knowledge on STEAM in chemistry. Coping, for this reason, a web-based STEAM online platform was designed. This paper reports the use of design-based research (DBR) to develop a web-based STEAM online platform. The paper focuses on two studies that step on the development and validation of the platform. In an attempt to implement theoretically designed learning environments in real-world classrooms, DBR was employed as an overarching framework of inquiry. The two cycles of DBR inquiry provide deep insights into the platform's readability, comprehensibility, and feasibility. The implementation of the framework is specified along with further implications for researchers and practitioners.

Keywords - Web-based STEAM online platform, Development, Validation, Design-based Research.

\section{To cite this article:}

Kartika, E.F.R., Susanti V.E., \& Indriyanti, N.Y. (2021). Development and validation of web-based STEAM online platform to improve learning quality in pre-service chemistry teachers. Journal of Technology and Science Education, 11(2), 513-525. https://doi.org/10.3926/jotse.1316

\section{Introduction}

Technology, digital devices, and service as a tool maybe became the most potent force for change in the $21^{\text {st }}$ century (Trilling \& Fadel, 2009). Today, our students are a net generation or what is often called "digital native", which are different from their parents and teachers (von der Heiden, Fleischer, Richert \& Jeschke, 2011). This phenomenon is changing both school and family. Sometimes students and teachers change roles, students become digital mentors, and teachers or parents become students (Trilling \& Fadel, 2009). This technology-driven development challenges many people's assumptions about what students should learn in school and how knowledge should be delivered (Lim, Chai \& Churchill, 2011).

For this reason, $21^{\text {st }}$-century learning needs to be developed. $21^{\text {st }}$-century learning improves students' competencies in technology for facing the challenges in their natural life (Luna, 2015) and for teachers and pre-service teachers, including chemistry subjects (Rusmansyah, Yuanita, Ibrahim, Isnawati \& Prahani, 
2019). Teachers and pre-service teachers should have superior competencies in the competitive era of globalization to teach their students, the $21^{\text {st }}$-century generation (Rusmansyah et al., 2019).

In $21^{\text {st }}$ century learning, technology must be an integral part of education to offer a more rigorous, creative, relevant, and engaging curriculum where the student must use and practice a $21^{\text {st }}$-century skill (Lambert \& Gong, 2010). However, there are gaps between the role and competencies of teachers and the use of technology in learning (Hatlevik, 2016). To overcome this gap, The Indonesian Ministry of National Education (MoNE) has attempted for the integration of information and communication of technology (ICT) in the teaching and learning process by providing ICT infrastructure in schools like computers, internet connection, and online learning content and also provide training and course to improve teachers competencies of technology (Ministry of National Education, 2010). One of them is by promoting learning that directly implements technology such as STEAM learning. The concept of technology in STEAM can be found in computational science and information technology (IT) education (Park \& Ko, 2012). Using STEAM, the teacher can improve their digital mastery and understanding of the technological system (Yakman, 2008). STEAM education using IT is an attractive educational method for the digital generation students to quickly and pleasantly learn the contents of mathematics, sciences, and technology (Bati, Yetişir, Çaliş̧kan, Güneş \& Saçan, 2018).

STEAM is the modern version of STEM (Yakman \& Lee, 2012). STEM and STEAM are different in the transdisciplinary approach (Herro \& Quigley, 2017). STEM studied direct learning activities that students do depends on mathematics and science, but STEAM emphasizes design, arts, creative thinking, and playful problem-solving to explore and create solutions (Herro \& Quigley, 2017). STEAM consists of five aspects science, technology, engineering, art, and mathematics. Each aspect has its meaning. Based on Yakman Framework, the content of IT describes informational technology under technology (T) (Park \& Ko, 2012). This definition is used for the differences between STEAM and STEM are art components. Art on STEAM consists of four elements, social arts, language arts, physical arts, and fine arts (Yakman, 2008). The researcher designed a web-based STEAM online platform that focuses on integrated technology and arts as a STEAM component in chemistry learning.

Chemistry is the subject that studies matter and the change, interaction, and rules that underlie changes. Learning chemistry means combining the concept of chemistry and the principle of education, this subject focus on how student understand chemical concepts that are often considered difficult (Sirhan, 2007). Chemistry is a complex subject, misconception (Üce \& Ceyhan, 2019), and student disinterest (Akram, Ijaz \& Ikram, 2017). as a primary cause that has dominated for a decade. Regarding disinterest being a hot topic among researchers, from the last two decades of the $20^{\text {th }}$ century, the concept of interest became a crucial factor in science education (Akram et al., 2017). The content taught without relevance in everyday life and no experimental learning that will increase curiosity cause student disinterest in chemistry (Krapp, 2005; Krapp \& Prenzel, 2011; Osborne, Simon \& Collins, 2003). Researchers argue that one reason students are interested in chemistry might be because of teaching methodology (Akram et al., 2017). STEAM can be applied as a teaching methodology that teaches chemistry contextually and relevant to everyday life (Ridwan \& Rahmawati, 2017). STEAM is an alternative that can increase student perception about chemistry, describe the complexities of learning chemistry, and increase students' positive perception of chemistry-based professions (Hannover \& Kessels, 2004; Rahmawati, Ridwan, Hadinugrahaningsih \& Soeprijanto, 2019).

The success of STEAM learning lies in the teachers as a central agent for implementing STEAM values and practice (Park, Byun, Sim, Han \& Baek, 2016). However, researchers had found teacher's difficulties in STEAM learning (Jho, Hong \& Song, 2016; Park et al., 2016). Difficulties experienced by teachers include lack of learning time, integration of material for STEAM learning, and intensive training (Jho et al., 2016). STEAM education often requires collaboration with teachers from other disciplines, and this is another problem because teachers have difficulty communicating due to cultural differences and the nature of scientific disciplines (Lee \& Shin, 2014). Another challenge teachers face is developing learning tools according to the STEAM learning format, especially in the assessment section (Lee \& Shin, 2014). In 
Indonesia, there are problems with many teachers who do not master digital and have difficulty developing learning tools according to the applicable curriculum (Nuraini, Tindangen \& Maasawet, 2016). Regarding STEAM, the innovation integration STEAM in chemistry subject within Indonesia context has been explored (Rahmawati et al., 2019).

Those findings are the basis for researchers to develop Web-based STEAM online platforms containing references related to how to implement STEAM in chemistry classes. This platform will support STEAM education by providing examples of chemistry lessons taught with STEAM. Like the United Kingdom with a nationwide network for STEM (STEMNET) and teachers' platforms, teachers will help teachers monitor and teach organizational skills in a digital world (Teachers.io). The web-based STEAM online platform is designed by combining two platforms (STEMNET and Teachers.io) to make it easier for teachers to prepare their classes.

The main objective of this work is to develop and construct a Web-based STEAM online platform that has the purpose of improving STEAM learning, of being a reference to implement STEAM in the classroom. In order to accomplish this aim, the following specific objectives were proposed:

a. To develop a web-based STEAM online platform using DBR research based on Reeves (Amiel \& Reeves, 2008)

b. To validate a web-based STEAM online platform and an educational website that can use as a reference for STEAM learning.

\section{Methodology}

This proposal is developed by a design-based research paradigm (Amiel \& Reeves, 2008; Chávez, Gámiz-Sánchez \& Vargas, 2015; Reeves, Herrington \& Oliver, 2005). It responds to the lack of perceptions and knowledge of STEAM of pre-service chemistry teachers. The problems detected in educational practice concerning integrating STEAM in chemistry learning. As a solution, a platform was designed as a reference regarding STEAM learning. The design of the web-based STEAM online platform was presented in Figure 1.

This platform is equipped with a menu containing the lesson plan template to overcome teacher's confusion in making lesson plans. The web-based STEAM online platform is a website. A website is a collection of pages in a domain that contains various information so that it can be read and seen by Internet users. The information posted on a website generally contains images, illustrations, videos, and text for various purposes. The web-based STEAM online platform has a domain address http://gurukreatif21.com. As the website manager, researchers will create an account for the user to $\log$ in to this website.

In order to design a web-based STEAM online platform, the researcher conducted a preliminary analysis. Preliminary analysis was used to determine the level of knowledge and perception of pre-service chemistry teachers about STEAM. The preliminary analysis consists of two stages. The first stage is a survey that consisted of single-question surveys-this survey was distributed to twenty-eight pre-service chemistry teachers. The second stage is a fully structured interview. This interview took for member checks what individuals said in surveys-the interview followed by eight pre-service chemistry teachers who answered better than others.

The development of a web-based STEAM online platform was done through three stages of the cycle. The first cycle is to know the readability and comprehensibility of the web-based STEAM online platform. This cycle used surveys and interviews with four pre-service chemistry teachers in the experimental class. The second cycle is to know the feasibility of Web-based STEAM online platform. Forum group discussion with the professional lecturers and teachers was focused on knowing the validity level of the Web-based STEAM online platform. The perception of eight pre-service chemistry teachers was also used to determine how suitable it is as a reference for STEAM-based chemistry learning. The last 
cycle is to determine the effectiveness of the Web-based STEAM online platform. This stage compared the integrated data from the experimental class and control class.

In this paper, the researcher reports the first and second cycles of Design-Based Research. The second cycle is carried out after reflection and improvement from the first cycle.

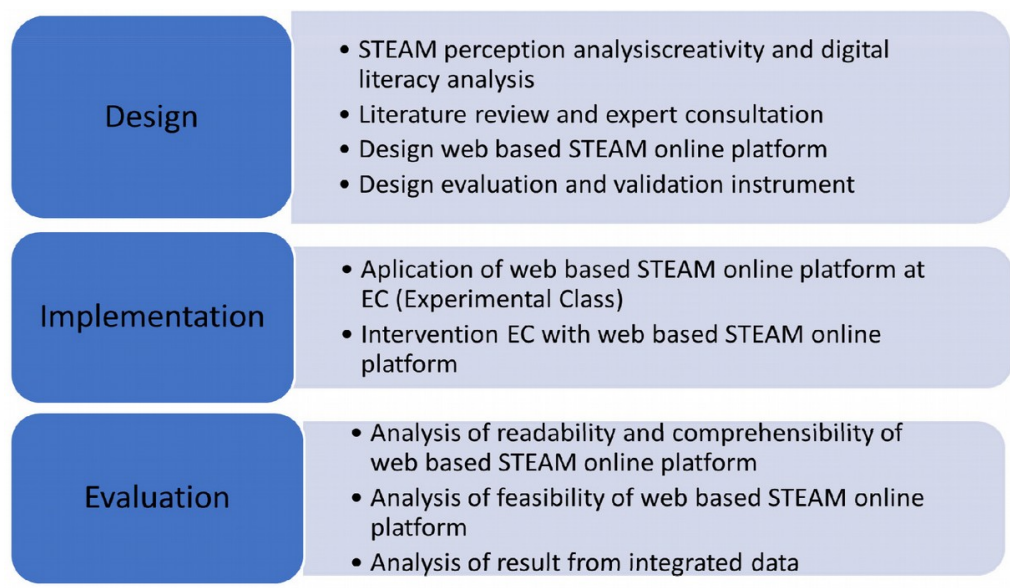

Figure 1. The Step of Development Web-based STEAM online platform

\subsection{Participant}

The research was conducted in one of the courses in the undergraduate program of chemistry education. All processes were conducted during the first semester of the 2020-2021 academic year. The first cycle of developing the web-based STEAM online platform involved four pre-service chemistry teachers in the experimental class. It was continued by a focus group discussion consisted of seven experts as well lecturers. Those experts are in media, language, content, STEAM, evaluation, and subject-specific pedagogy (SSP). The perception of ten pre-service chemistry teachers in the experimental class was also used in the second cycle of developing the web-based STEAM online platform. The last cycle involved seventy-four pre-service chemistry teachers who were divided into experimental class and control class. All the pre-service chemistry teachers are the $2^{\text {nd }}$ year students at the department of chemistry education in a public university in Surakarta City, Indonesia. There are no specific criteria for participants in this research, all pre-service chemistry teachers were involved and volunteered in this research, so the researchers chose participants randomly. Sample characteristics are presented in Table 1.

\begin{tabular}{|l|c|c|c|}
\hline \multicolumn{2}{|c|}{ Variable } & $\begin{array}{c}\text { CC } \\
\text { (Control Class) }\end{array}$ & $\begin{array}{c}\text { EC } \\
\text { (Experimental Class) }\end{array}$ \\
\hline \multicolumn{2}{|l|}{ Range Age } & $18-20$ & $18-20$ \\
\hline \multicolumn{2}{|l|}{ Year of Study } & $2^{\text {nd }}$ & $2^{\text {nd }}$ \\
\hline \multirow{2}{*}{ Sex } & Female & $32 / 86,5 \%$ & $35 / 94,5 \%$ \\
\cline { 2 - 4 } & Male & $5 / 13,5 \%$ & $2 / 5,5 \%$ \\
\hline \multicolumn{2}{|l|}{ Total $=74$} & 37 & 37 \\
\hline
\end{tabular}

Table 1. Characteristic and Distribution of the sample

\subsection{Instrumentation}

The web-based STEAM online platform was designed by involving the survey and interview conducted to twenty-eight pre-service chemistry teachers studying the $3^{\text {rd }}$ year students at the department of chemistry education in a public university in Surakarta, Indonesia. The survey consists of 18 questions from six aspects of STEAM. There are initial understanding of the STEAM concept, STEAM application in chemistry, development of STEAM-based learning and STEAM's contribution to learning, the challenges 
of implementing STEAM, and STEAM implementation (Conner, Tzou, Tsurusaki, Guthrie, Pompea \& Teal-Sullivan, 2017; Connor, Karmokar \& Whittington, 2015; Hong, 2016; Jho, Hong \& Song, 2016; Lee \& Shin, 2014). A fully structured interview was used with eleven questions for a member to check answered in surveys.

A website-based platform was designed using a plugin from WordPress. It is a website that users need to $\log$ in using a username and password. TAP (Think Aloud Protocol) was used in the first cycle to know the readability and comprehensibility of the website (Fonteyn, Kuipers \& Grobe, 1993). Aiken's validation using seven raters (judge) was used to validate the feasibility of the website. The validation procedure concerned the content validity and reliability, expressed in dichotomies or rank terms (Aiken, 1980). The perception of eight pre-service chemistry teachers was observed using surveys.

\subsection{Procedure for the Integration of Web-based STEAM Online Platform}

The web-based STEAM online platform was applied during the first semester of the academic year 2020/2021 to Learning Technology Course. This course has intended learning outcomes that chemistry teachers could develop a chemistry learning media integrated with technology. This movement is directly linked to the skills of the $21^{\text {st }}$ century to be a master of technology (Luna, 2015).

The learning was carried out in an online learning mode. In this case, it requires a platform to be able to teach STEAM in more detail. The STEAM platform design is an alternative to overcoming online learning and as a reference for teachers in overcoming difficulties when designing online learning. The project was established with the pre-service chemistry teachers within the six weeks into which STEAM was organized. The presentation of the work was made in the next week after they received STEAM material and how it integrated into the chemistry topic. In the lesson plan, this subject comprises three topics of chemistry learning media: E-Poster, Podcast, and Video. The time distributed to the topic in both control and experimental class can be seen in Table 2. Each activity took a total of two hours of classes (100 minutes).

STEAM learning using the STEAM online web-based platform only taught an experimental class. In the lectures and practical classes, the pre-service chemistry teachers were questioned about the aspect and framework of STEAM. There was a discussion about how to integrate the aspect of technology and arts in chemistry learning. This learning focuses on producing chemistry-learning media (e-poster, podcast, video) integrated with STEAM. Because the material taught is on ICT-based learning media, researchers chose to focus on the integrated aspect of technology and arts on chemistry.

The methodology applied in control class (CC) is a traditional method based on the delivery of theoretical lectures, each of the listed topics, respectively. Concerning the lecturer (L), presentational methods were used to discuss the learning content. A practical class (PC) was established based on the initial lecturer orientation of exercises and problems at the beginning of each period. The last is a reflection session to review the responses given to the project that had been made.

\begin{tabular}{|l|c|c|c|c|c|c|}
\hline \multirow{2}{*}{} & \multicolumn{2}{|c|}{ Topic 1 (E- Poster) } & \multicolumn{2}{c|}{ Topic 2 (Podcast) } & \multicolumn{2}{c|}{ Topic 3 (Video) } \\
\cline { 2 - 7 } & Week 1 & Week 2 & Week 3 & Week 4 & Week 5 & Week 6 \\
\hline EC & L \& PC & Ref & L \& PC & Ref & L \& PC & Ref \\
\hline CC & L \& PC & Ref & L \& PC & Ref & L \& PC & Ref \\
\hline
\end{tabular}

EC: Experimental Class; CC: Control Class; L: Lectures; PC: Practical Classes; Ref: Reflection

Table 2. Time Distribution of the study plan in the Experimental Class (EC) and Control Class (CC)

\subsection{Data Collection}

In all studies, qualitative analysis of students' reflections, interviews, and focus groups were employed to identify how STEAM online web-based platform can improve STEAM learning in pre-service chemistry teachers. Table 3 summarizes the data collected in the three testings. 


\begin{tabular}{|c|c|}
\hline Data & Purpose \\
\hline \multicolumn{2}{|l|}{ Cycle 1} \\
\hline TAP (Think Aloud Protocol) & $\begin{array}{l}\text { Overview of the use of Web-based STEAM online platform } \\
\text { An obstacle faced by using Web-based STEAM online platform } \\
\text { Reflection on the part of Web-based STEAM online platform that needs to be } \\
\text { fixed }\end{array}$ \\
\hline Participant & $\begin{array}{l}\text { Two male and two female students } \\
\text { Age: } 18-20 \text { years }\end{array}$ \\
\hline \multicolumn{2}{|l|}{ Cycle 2} \\
\hline a. Focus Group Discussion & $\begin{array}{l}\text { Overview of the usability, functionality, content, and visual communication on } \\
\text { Web-based STEAM online platform }\end{array}$ \\
\hline Participant & Eight professional lecturers \\
\hline b. Student's reflection & $\begin{array}{l}\text { Overview and reflection of the content, display, language, graphics, and technique } \\
\text { of use of the Web-based STEAM online platform }\end{array}$ \\
\hline Participant & $\begin{array}{l}\text { Ten female students } \\
\text { Age: } 18-20 \text { years }\end{array}$ \\
\hline
\end{tabular}

Table 3. Development of Web-based STEAM online platform in three Stages of Testing

\section{Result and Finding}

The first aspect to highlight is the low perception of pre-service chemistry teachers in STEAM learning. The response of perception of pre-service chemistry teachers was presented in Figure 2.

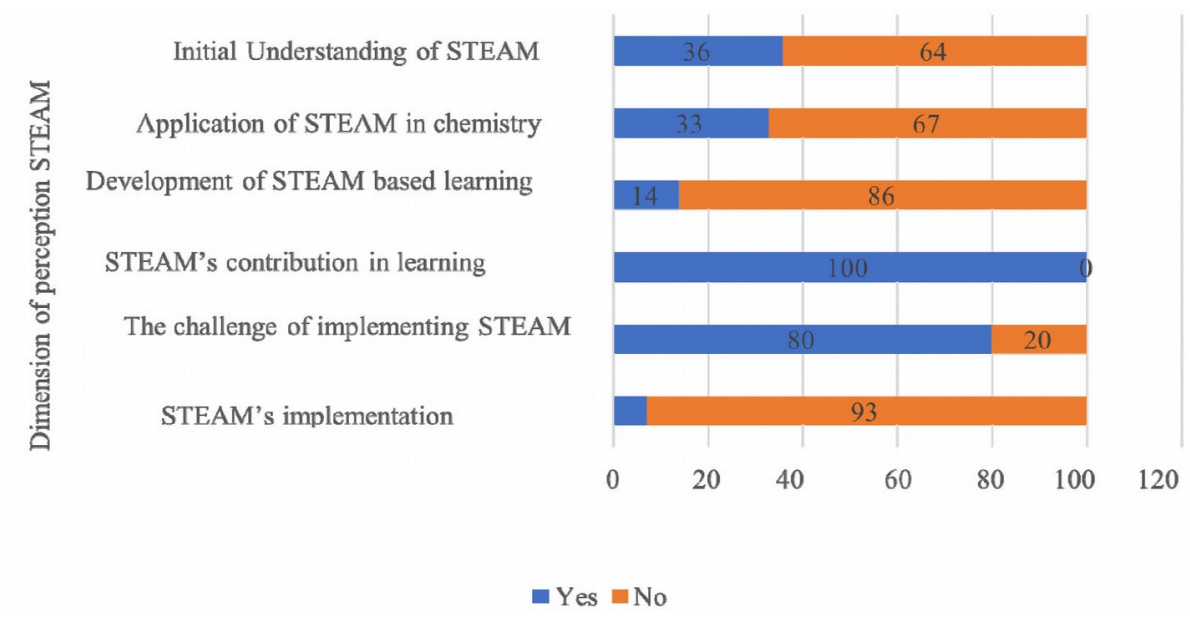

Figure 2. Response of Perception of Pre-Service Chemistry Teachers Toward STEAM

Based on Figure 2, in the initial understanding of STEAM, 64\% of participants just knowing STEAM in general term, they feel confused about what STEAM is an approach or a learning model. All the participants said that STEAM could integrate into chemistry, 33\% said that STEAM could apply all chemistry topics, and $67 \%$ said it was not. Most participants mentioned that chemistry topics that can be integrated with STEAM are redox, acid-base, hydrocarbon, periodic system of the element, and solubility and solubility product. Only 14\% of participants almost correctly develop STEAM-based learning tools, and no one was successfully linking STEAM to the learning model and allocate the right time for integrated STEAM in chemistry learning. All the participants said that STEAM contributes to chemistry learning; it can decrease the disinterest in chemistry. $80 \%$ of participants found that integration of STEAM in chemistry learning was a challenge. Not all students are interested in arts, lack class hours to apply STEAM, and not all teachers who master art have difficulties implementing STEAM in chemistry learning. In the STEAM implementation, only $7 \%$ of participants can explain the STEAM framework, and the others found it challenging to construct a STEAM project. 
After Surveys, the researchers selected eight pre-service chemistry teachers with the correct answer to be interviewed. Based on their response to interviews, STEAM is challenging to integrate into chemistry learning. Their perception is still in the lows level category, and they do not understand STEAM learning because they are not familiar with it. According to Bati et al. (2018), almost all countries found that integrating STEAM in class is challenging. The difficulty of time management, insufficient instructional materials, long duration of some activities, not all teachers are creative, and master of arts cause STEAM to be challenging to integrate (Jho et al., 2016).

The website consists of five menus: home, class, Lesson plan, chemistry issue, and account. The home button consists of a schedule where users can fill as a reminder and a user manual to operate the website. The class consists of topic chemistry integrated with STEAM as a reference. In this menu, the user can find some chemistry topics and how integrated STEAM in that topic. The lesson plan contains an appropriate format based on The Indonesian Ministry of National Education (MoNE). Chemistry's issue is a menu containing an example of a chemistry topic integrated with STEAM. Users can upload their project in this menu, such as podcasts, videos, or e-poster integrated with STEAM, and another user can see the project. The account consists of several questions related to user's profiles. The display of the web-based STEAM online platform was presented in Figure 3.

On this website, STEAM is shown in the classes menu and chemistry's issue. In the class's menu, users can see how to integrate STEAM in chemistry subjects and use this information as references. Based on (Indriyanti, Kartika \& Susanti, 2021), STEAM is unfamiliar in pre-service chemistry teachers, and they found it challenging to integrate STEAM in chemistry. For this reason, many teachers in Korea also have difficulty selecting a topic, developing educational materials, integrating subjects, and evaluating classes (Hong, 2018). Therefore, this website provides an overview of how to integrate STEAM in chemistry along with suitable media. In chemistry's issue's menu presents examples of media created by other users, such as e-posters, videos, and podcasts integrated with STEAM. This platform can help pre-service chemistry teachers who have difficulty designing learning media integrated with STEAM.

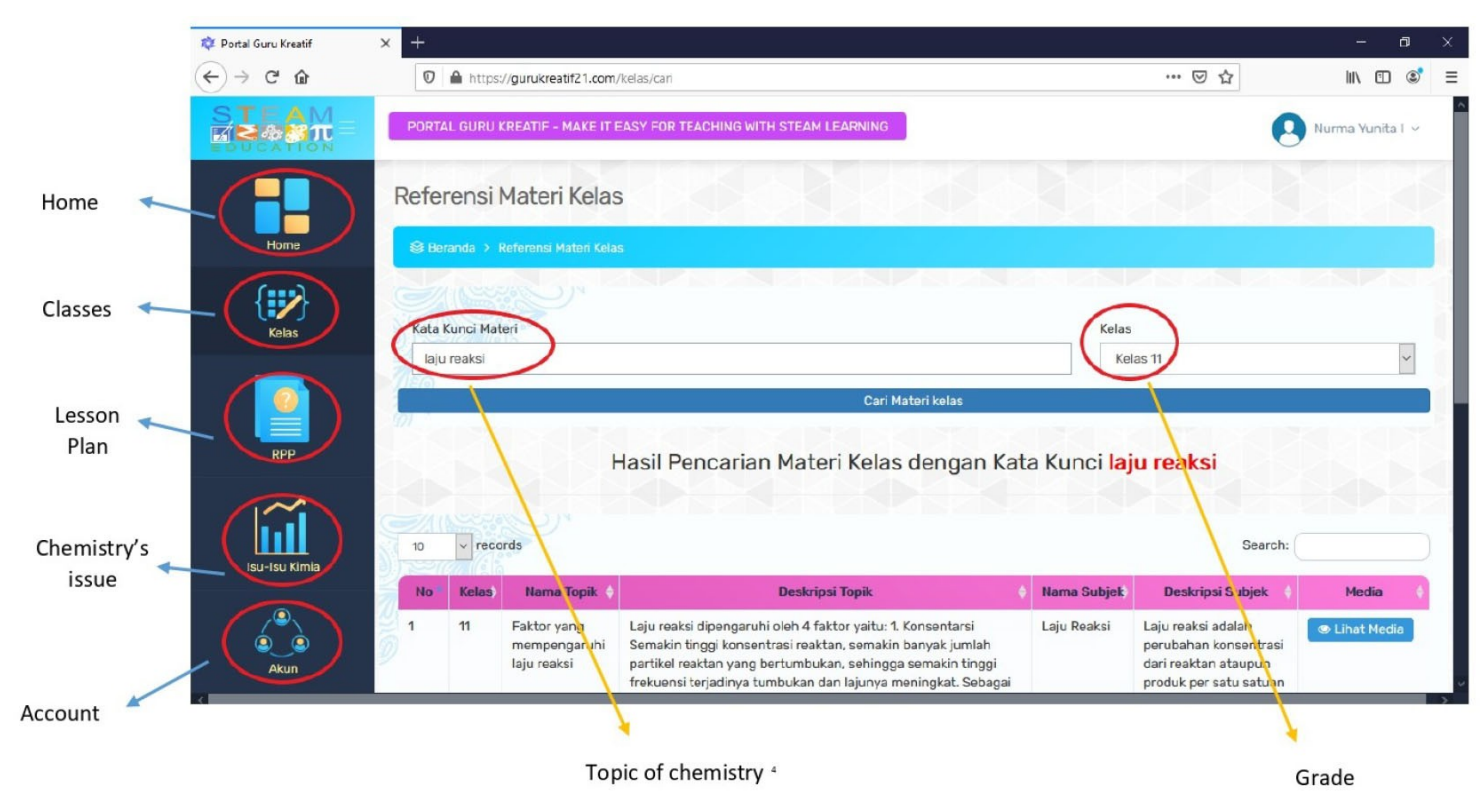

Figure 3. Display of Web-based STEAM online platform

\subsection{Cycle 1}

This cycle explored the readability and comprehensibility of Web-based STEAM online platforms. Throughout this cycle, the student was involved using TAP (Think Aloud Protocol). In TAP, the facilitator asks the student to use the Web-based STEAM online platform while continuing to think aloud, only 
verbalizing their thoughts as they move through the user interface. The TAP method serves as a window to the soul, enabling researchers to discover what users think about the researcher's design (Fonteyn et al., 1993). In particular, listen to their misconceptions that usually turn into actionable redesign recommendations. Even researchers can learn why users guess wrong about some parts and why they find others easy to use.

In this research, TAP involved four participants (two females and two males) in the experimental class. They are selected randomly. In the TAP process, the researcher gives several times to participants operate the website and asking about their confusion when operating the website. In the last session of this TAP, participants provide some suggestions for website improvement. This cycle resulted in website configuration, such as some icons that need to be added to the website. The development of the website was achieved in the following parts:

a. They were adding a user manual in the Home menu. The user manual is focused on being a guide to using the website. Based on the result of the TAP cycle, participants experience confusion regarding the function of the menu and icon. However, pre-service chemistry teachers who will become future teachers are digital natives whose all activities are related to technology (von der Heiden et al., 2011) do not all have high levels of digital literacy.

b. It is adding grade choices in the Classes menu so that it is easier to find chemistry topics. In Indonesia, chemistry is taught in high school and is divided into three grade levels. Each grade consists of different chemical materials, so it is easier to search the topic if given a different grade.

Participants explored several responses and suggestions when they use the website. Based on their responses, the researchers use it for reflection and improvement of the website. Some of the responses are:

"This means there will be some integration of teachers in this system, miss? For example, as a chemistry teacher, in a school, the teachers made something like STEAM integration in some material, I made a project on the topic of rate of the reaction and Iqbal made in the topic of acid-base theory, so my work. can be used by other people, miss?"

(Participant 1, 12 October 2020)

"In my opinion, it is easy (user friendly) but if from the beginning we did not know the function of each menu and bow the operation of the web became difficult, but if it has been told it is easy, especially for the digitally literate millennial generation."

(Participant 2, 12 October 2020)

The responses stated that they are excited to operate the website to improve their digital literacy and technology literacy. Pre-service teachers are the digital native generation who will teach a student from digital natives too; they must be master technology. Pre-service teachers should know what the student must learn in the classroom with technology (Luna, 2015). Technology is one aspect of STEAM as a skill or system used in the organization, governing society, knowledge, and design, and using a tool made to facilitate the work (Utomo, Hasanah, Hariyadi, Narulita, Suratno \& Umamah, 2020). Operate this website is expected can improve digital literacy skills from pre-service chemistry teachers.

\subsection{Cycle 2}

This cycle explored the feasibility of Web-based STEAM online platform. Focus group discussion was held to validate and to know how feasibility is the Web-based STEAM online platform. The lecture gives several suggestions about Web-based STEAM online platform. Based on the result of Aiken's validation given value of 0.96 , that means this website is valid. Based on the Aiken rules, the validation value is based on the number of raters involved, adjusted to the table; if the validation value is higher than the table value, it is considered valid (Aiken, 1985). The result of the focus group discussion provides the following suggestion in Table 4. 


\begin{tabular}{|l|l|}
\hline \multicolumn{1}{|c|}{ Professional Lecturer } & \multicolumn{1}{c|}{ The Suggestion } \\
\hline Expert of learning media & $\begin{array}{l}\text { Adding an icon for inputting media in the lesson plan menu and an icon for } \\
\text { downloading the lesson plan can be a library for users. }\end{array}$ \\
\hline Expert of STEAM & $\begin{array}{l}\text { Adding more examples of integrating STEAM in the chemistry materials and how } \\
\text { to teach them to the student in the classes menu }\end{array}$ \\
\hline Expert of language & $\begin{array}{l}\text { In the home menu, in the agenda section, the format needs to be changed to input } \\
\text { more than one agenda to remind users who are pre-service teachers. }\end{array}$ \\
\hline
\end{tabular}

Table 4. The suggestion of the development of Web-based STEAM online platform from Professional Lecturer

The media inserted in the lesson plan menu is the user's use when teaching chemistry. Media has the following meaningful value: (1) can overcome student's limited experience, (2) can overcome the limitation of the classroom (3) can overcome the limitation of student's understanding of the materials (Utomo et al., 2020). In this case, the media being developed is integrated with STEAM. The implementation of the media with STEAM is expected to improve the means of learning. STEAM, especially in arts, is an effective way of introducing science and mathematics for students (Ge, Ifenthaler \& Spector, 2015). The arts as language arts is for communication language that makes it easier to explain science concepts to students (Yakman \& Lee, 2012). The media that is integrated with STEAM designed by the user is expected to explain chemistry more easily. Media created and uploaded on the web as a user library can be repeatedly used when teaching.

Based on the preliminary analysis, STEAM is challenging to implement in the chemistry subject (Indriyanti et al., 2021). Adding some references on how to integrate STEAM on chemistry topics can overcome the challenge by providing an overview of the implementation of STEAM in class. References are described on the website regarding the STEAM implementation framework and designing STEAM media or projects for students. This platform is expected to make it easier for users to integrate STEAM into chemistry.

Change the format of the agenda in the home section to be like a schedule format to write down all his teaching schedules. The agenda format contains teaching time, chemistry topics, projects to be made by students, and the assessments used. This menu can increase the use-value of the Web-based STEAM online platform.

Student reflection is also used to explore the content, display, language, graphics, and technique of using the Web-based STEAM online platform. The result of this reflection are presented in Figure 4.

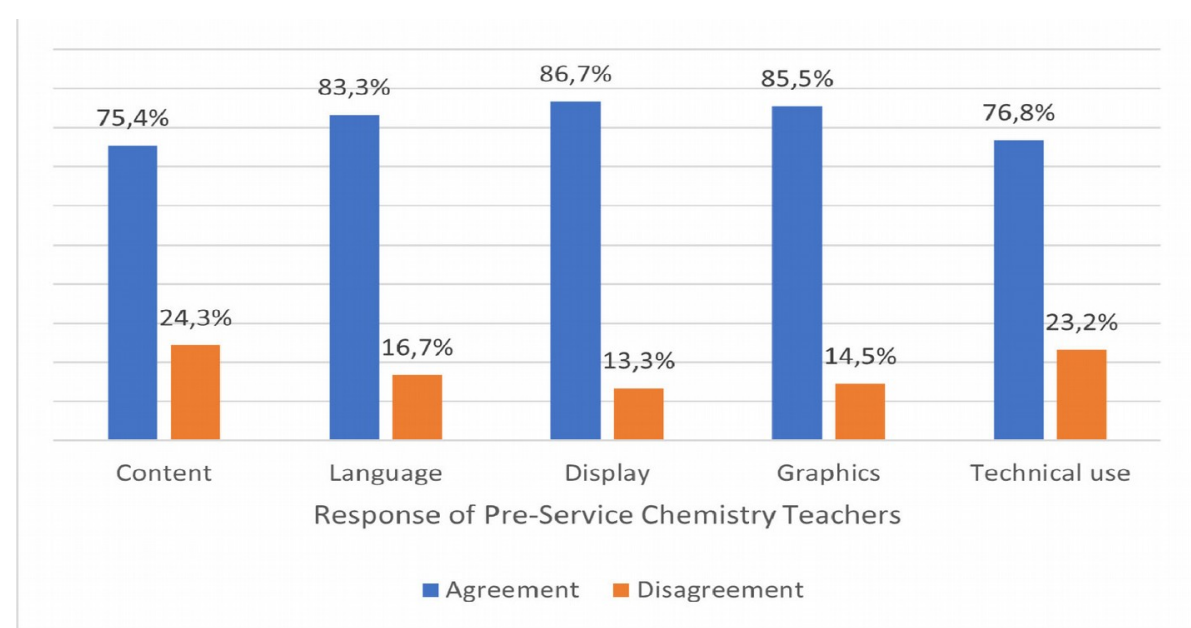

Figure 4. The Result of Response in Cycle 2

The result of pre-service chemistry teachers' responses in terms of content, language, display, graphics, and technical use in Figure 4 show that the web-based STEAM Online platform has a pretty good 
percentage above $75 \%$ which means this website meets feasibility. In the aspect of content, pre-service chemistry teachers agree that this website gives information about STEAM and can reference how to integrate STEAM in chemistry. Relating STEAM to chemistry concepts was challenging (Hadinugrahaningsih, Rahmawati, Ridwan, Budiningsih, Suryani, Nurlitiani et al., 2017); pre-service chemistry teachers feel helped by this website; they can learn examples of STEAM projects on several chemistry topics available in the classic and chemistry issue's menu. Regarding preliminary analysis (Indriyanti et al., 2021), most pre-service chemistry teachers are not familiar with STEAM; this website references them to integrate STEAM in chemistry learning and be a provision when they teach later. Pre-service chemistry teachers seemed enthusiastic about the web-based STEAM Online platform. They agree that language, graphics, and technical use in this website are clear, but several parts are lacking. Some of them suggesting the improvement of the website as follows:

a. My suggestion may be that the chemistry section in the classes menu must be completed in more detail. The chemical issues section is already exciting and equipped with supporting media; it looks attractive and easier to use (Participant 6, 19 October 2020).

b. I think this website is fascinating and promising. Using this website will make it easier for teachers to provide innovative learning in the classroom. On this website, the menus are neatly arranged. However, access to this web is slow in some areas, so large bandwidth is needed to make it easier to access the website (Participant 10, 19 October 2020).

As the research participant, pre-service chemistry teachers are the digital native generation, and they are pretty tech-savvy. If this web-based STEAM online platform is used in "regular" learning, it will not give different results when used in online learning like the current condition. In "normal" learning, this website can be used in blended learning.

\section{Conclusions}

It has been developed and validated a Web-based STEAM online platform. It has also been an appropriate format to design lesson plans. The researcher has achieved a reference that allows accessible data acquisition about integrating STEAM in chemistry learning. When pre-service teachers who became future teachers work with this website, they are prepared material for teaching and improve their knowledge to teach chemistry in content and context. It has been a satisfactory experience for pre-service teachers in charge of the practices. In this way, pre-service teachers can reach a new technology that is not typically seeing in their environment. The study gives results that the website meets the validity according to the Aiken standard with a value of 0.96 . Pre-service chemistry teachers enthusiastic about the website, and they give some suggestions for the website's improvement. Based on the suggestion, Researchers make improvements to the website to be suitable for use in learning. The principal drawback is that the practices are developed in small groups so that the results are less general; it is necessary to add more research subjects. This website can be used in all chemistry education programs in other universities but not for other science disciplines such as biology and physics.

\section{Declaration of Conflicting Interests}

The authors declared no potential conflicts of interest with respect to the research, authorship, and/or publication of this article.

\section{Funding}

The authors received no financial support for the research, authorship, and/or publication of this article.

\section{References}

Aiken, L.R. (1980). Content validity and reliability of single items or questionnaires. Educational and Psychological Measurement, 40(4), 955-959. https://doi.org/10.1177/001316448004000419 
Aiken, L.R. (1985). Three coefficients for analysing Reliability and Validity of rating. Educational and Psychological Measurement, 45, 131-142. https://doi.org/10.1177/07399863870092005

Akram, T.M., Ijaz, A., \& Ikram, H. (2017). Exploring the Factors Responsible for Declining Students' Interest in Chemistry. International Journal of Information and Education Tecbnology, 7(2), 88-94. https://doi.org/10.18178/ijiet.2017.7.2.847

Amiel, T., \& Reeves, T.C. (2008). Design-based research and educational technology: Rethinking technology and the research agenda. Educational Technology and Society, 11(4), 29-40.

Bati, K., Yetişir, M.I., Çalişkan, I., Güneş, G., \& Saçan, E.G. (2018). Teaching the concept of time: A steam-based program on computational thinking in science education. Cogent Education, 5(1), 1-16. https://doi.org/10.1080/2331186X.2018.1507306

Chávez, D.A., Gámiz-Sánchez, V.M., \& Vargas, A.C. (2015). Problem-Based Learning: Effects On Academic Perfomence and Perceptions Of Engineering Students In Computer Sciences. Journal of Technology and Science Education, 5(3), 184-193.

Conner, L.D.C., Tzou, C., Tsurusaki, B.K., Guthrie, M., Pompea, S., \& Teal-Sullivan, P. (2017). Designing STEAM for Broad Participation in Science. Creative Education, 08(14), 2222-2231. https://doi.org/10.4236/ce.2017.814152

Connor, A.M., Karmokar, S., \& Whittington, C. (2015). From STEM to STEAM: Strategies for Enhancing Engineering \& Technology Education. International Journal of Engineering Pedagogy (IJEP), 5(2), 37. https://doi.org/10.3991/ijep.v5i2.4458

Ministry of National Education (2010). Rencana Strategis 2010-2014. Rencana Strategis.

Fonteyn, M.E., Kuipers, B., \& Grobe, S.J. (1993). A Description of Think Aloud Method and Protocol Analysis. Qualitative Health Research, 3(4), 430-441. https://doi.org/10.1177/104973239300300403

Ge, X., Ifenthaler, D., \& Spector, J.M. (2015). Moving Forward with STEAM Education Research. In Emerging Technologies for STEAM Education (383-395). https://doi.org/10.1007/978-3-319-02573-5

Hadinugrahaningsih, T., Rahmawati, Y., Ridwan, A., Budiningsih, A., Suryani, E., Nurlitiani, A., et al. (2017). Keterampilan Abad 21 dan STEAM (Science, Technology, Engineering, Art, and Mathematics) Project dalam Pembelajaran Kimia. In LPPM Universitas Negeri Jakarta. https://doi.org/10.1017/CBO9781107415324.004

Hannover, B., \& Kessels, U. (2004). Self-to-prototype matching as a strategy for making academic choices. Why high school students do not like math and Science. Learning and Instruction, 14(1), 51-67. https://doi.org/10.1016/j.learninstruc.2003.10.002

Hatlevik, O.E. (2016). Examining the Relationship between Teachers' Self-Efficacy, their Digital Competence, Strategies to Evaluate Information, and use of ICT at School. Scandinavian Journal of Educational Research, 61(5), 555-567. https://doi.org/10.1080/00313831.2016.1172501

Herro, D., \& Quigley, C. (2017). Exploring teachers' perceptions of STEAM teaching through professional development: implications for teacher educators. Professional Development in Education, 43(3), 416-438. https://doi.org/10.1080/19415257.2016.1205507

Hong, O. (2016). STEAM Education in Korea: Current Policies and Future Directions Science and Technology Trends Policy Trajectories and Initiatives in STEM Education STEAM Education in Korea: Current Policies and Future Directions. Policy Trajectories and Initiatives in STEM Education (90-102). https://www.researchgate.net/publication/328202165 
Hong, O. (2018). STEAM Education in Korea: Current Policies and Future Directions. In Science and Technology Trends (92-102). http://www.p21.org

Indriyanti, N.Y., Kartika, E.F.R., \& Susanti, E. (2021). Pre-Service Teachers’ Perception in Integrating STEAM in Chemistry Learning, In AIP Conference Proceedings (2331, 040031). https://doi.org/10.1063/5.0041842

Jho, H., Hong, O., \& Song, J. (2016). An analysis of STEM/STEAM teacher education in Korea with a case study of two schools from a community of practice perspective. Eurasia Journal of Mathematics, Science and Technology Education, 12(7), 1843-1862. https://doi.org/10.12973/eurasia.2016.1538a

Krapp, A. (2005). Basic needs and the development of interest and intrinsic motivational orientations. Learning and Instruction, 15(5), 381-395. https:/ / doi.org/10.1016/j.learninstruc.2005.07.007

Krapp, A., \& Prenzel, M. (2011). Research on interest in Science: Theories, methods, and findings. International Journal of Science Education, 33(1), 27-50. https://doi.org/10.1080/09500693.2010.518645

Lambert, J., \& Gong, Y. (2010). 21st Century paradigms for pre-service teacher technology preparation. Computers in the Schools, 27(1), 54-70. https://doi.org/10.1080/07380560903536272

Lee, J.M., \& Shin, Y.J. (2014). An Analysis of Elementary School Teachers' Difficulties in the STEAM Class. Elementary Science Education, 33(3), 588-596. https://doi.org/10.15267/keses.2014.33.3.588

Lim, C.P., Chai, C.S., \& Churchill, D. (2011). A framework for developing pre-service teachers' competencies in using technologies to enhance teaching and learning. Educational Media International, 48(2), 69-83. https:// doi.org/10.1080/09523987.2011.576512

Luna, C. (2015). The Futures of learning 2: what kind of learning for the 21st century? Education Research and Foresight: working papers.

Nuraini, N., Tindangen, M., \& Maasawet, E.T. (2016). Analisis Permasalahan Guru Terkait Perangkat Pembelajaran Berbasis Model Inquiry Dan Permasalahan Siswa Terkait Kemampuan Pemecahan Masalah Dalam Pembelajaran Biologi Di Sma. Jurnal Pendidikan - Teori, Penelitian, Dan Pengembangan, 1(10), 2066-2070. https://doi.org/10.17977/jp.v1i10.7653

Osborne, J., Simon, S., \& Collins, S. (2003). Attitudes towards Science: A review of the literature and its implications. International Journal of Science Education, 25(9), 1049-1079. https://doi.org/10.1080/0950069032000032199

Park, H.J., Byun, S.Y., Sim, J., Han, H., \& Baek, Y.S. (2016). Teachers' perceptions and practices of STEAM education in South Korea. Eurasia Journal of Mathematics, Science and Technology Education, 12(7), 1739-1753. https://doi.org/10.12973/eurasia.2016.1531a

Park, N., \& Ko, Y. (2012). Computer Education' s Teaching-Learning Methods STEAM Education To cite this version: HAL Id: Hal-01551331. 9th International Conference on Network and Parallel Computing (NPC), 320-327. https://doi.org/10.1007/978-3-642-35606-3_38

Rahmawati, Y., Ridwan, A., Hadinugrahaningsih, T., \& Soeprijanto. (2019). Developing critical and creative thinking skills through STEAM integration in chemistry learning. Journal of Physics: Conference Series, 1156(1). https://doi.org/10.1088/1742-6596/1156/1/012033

Reeves, T.C., Herrington, J., \& Oliver, R. (2005). Design Research: A Socially Responsible Approach to Instructional Technology Research in Higher Education. Journal of Computing in Higher Education Spring, 16(2). http://www.carnegiefoundation.org/ https://doi.org/10.1007/BF02961476 
Ridwan, A., \& Rahmawati, Y. (2017). Steam Integration in Chemistry Learning for Developing $21^{\text {St }}$ Century Skills. MIER Journal of Educational Studies, Trends \& Practices, 7(2), 184-194. https://doi.org/10.52634/mier/2017/v7/i2/1420

Rusmansyah, R., Yuanita, L., Ibrahim, M., Isnawati, I., \& Prahani, B.K. (2019). Innovative chemistry learning model: Improving the critical thinking skill and self-efficacy of pre-service chemistry teachers. Journal of Technology and Science Education, 9(1), 59-76. https://doi.org/10.3926/jotse.555

Sirhan, G. (2007). Learning Difficulties in Chemistry: An Overview. Journal of Turkish Science Education, $4(2), 2-20$.

Trilling, B., \& Fadel, C. (2009). 21 st Century Skills: Learning for Life in Our Times. Jossey-Bass/Wiley.

Üce, M., \& Ceyhan, İ. (2019). Misconception in Chemistry Education and Practices to Eliminate Them: Literature Analysis. Journal of Education and Training Studies, 7(3), 202. https://doi.org/10.11114/jets.v7i3.3990

Utomo, A.P., Hasanah, L., Hariyadi, S., Narulita, E., Suratno, \& Umamah, N. (2020). The effectiveness of STEAM-based biotechnology module equipped with flash animation for biology learning in high school. International Journal of Instruction, 13(2), 463-476. https://doi.org/10.29333/iji.2020.13232a

von der Heiden, B., Fleischer, S., Richert, A., \& Jeschke, S. (2011). Theory of digital natives in the light of current and future E-learning concepts. International Journal of Emerging Technologies in Learning, 6(2), 37-41. https://doi.org/10.3991/ijet.v6i2.1555

Yakman, G., \& Lee, H. (2012). Exploring the Exemplary STEAM Education in the U.S. as a Practical Educational Framework for Korea. Journal of The Korean Association For Science Education, 32(6), 1072-1086. https://doi.org/10.14697/jkase.2012.32.6.1072

Yakman, G. (2008). STEAM Education: an overview of creating a model of integrative education. PATT-17 and PATT-19 Proceedings (335-358). https: $/ /$ www.iteea.org $/$ File. $a s p x ? i d=86752 \& v=75 \mathrm{ab} 076 \mathrm{a}$

Published by OmniaScience (www.omniascience.com) Journal of Technology and Science Education, 2021 (www.jotse.org)

\section{(c) (1) (9)}

Article's contents are provided on an Attribution-Non Commercial 4.0 Creative commons International License. Readers are allowed to copy, distribute and communicate article's contents, provided the author's and JOTSE journal's names are included. It must not be used for commercial purposes. To see the complete licence contents, please visit https://creativecommons.org/licenses/by-nc/4.0/. 